(C) Copyright 2019: Editum. Servicio de Publicaciones de la Universidad de Murcia. Murcia (Spain) ISSN print edition: 0212-9728. ISSN on line edition (http://revistas.um.es/analesps): 1695-2294. On line edition License Creative Commons 4.0: BY-NC-ND

\title{
Validation of the Dependency-Oriented and Achievement-Oriented Psychological Con- trol Scale (DAPCS) in a Spanish-speaking late adolescent sample
}

\author{
Omar García-Pérez*, Carmen Rodríguez-Menéndez, Susana Torío-López, and Sara Rodríguez-Pérez
}

Facultad de Formación del Profesorado y Educación. Universidad de Oviedo (Spain)

Título: Validación de la Escala de Control Psicológico Orientado a la Dependencia y al Logro (DAPCS) en una muestra de adolescentes tardíos que hablan español.

Resumen: El control psicológico parental se refiere a los comportamientos de los padres que interfieren con los pensamientos y sentimientos de niño y se caracterizan por el uso excesivo de técnicas de manipulación, como la inducción de culpa o vergüenza y la retirada del afecto. Este estudio tuvo como objetivo validar la versión en español de la Dependencyoriented and Achievement-oriented Psychological Control Scale (DAPCS) (Escala de control psicológico orientado a la dependencia y control psicológico orientado al logro), una nueva medida diseñada para evaluar la percepción del control psicológico de un adolescente. Otro objetivo fue determinar la influencia del control psicológico parental percibido sobre el autoconcepto de los adolescentes. Evaluamos la estructura factorial, la fiabilidad y la validez convergente en una muestra de adolescentes tardíos españoles $(N=310$, edad media $=19.75)$. Los análisis de factores exploratorios y confirmatorios mostraron que la estructura factorial de la escala DAPCS se describe mejor con una solución de 2 factores, tanto para padres como para madres, lo que indica la distinción entre control psicológico orientado a la dependencia y el orientado al logro. Los altos índices de consistencia interna indicaron que la escala DAPCS produjo óptimas puntuaciones. Además, la validez convergente fue confirmada por la correlación entre el DAPCS y otras medidas de control psicológico, así como con otras medidas del análisis de la crianza. La regresión jerárquica también mostró que DAPCS predijo el autoconcepto de los adolescentes tardíos. Los resultados de este estudio indican que la versión en español de DAPCS es un instrumento útil para estudiar ambos tipos de control psicológico.

Palabras clave: control psicológico orientado a la dependencia; control psicológico orientado al logro; estilo educativo parental; autoconcepto; adolescencia.

\section{Introduction}

In recent decades, research about parenting has exhibited a strong interest in parental psychological control. We want to highlight Barber's (1996) traditional division between psychological control and behavioral control for its importance and influence. Psychological control refers to those parental behaviors that interfere with a child's thoughts and feelings, which are characterized by excessive use of manipulative techniques such as inducing guilt or shame and lovewithdrawal. Children who consistently perceive that their parents always try to change them to suit their needs or who experience parental manipulation of their feelings and emotions have more difficulty recognizing their own autonomy

* Correspondence address [Dirección para correspondencia] Omar García-Pérez. Facultad de Formación de Profesorado y Educación. C/ Aniceto Sela s/n. 33005 Oviedo, Asturias (Spain).

E-mail: garciaomar@uniovi.es

(Article received: 04-05-2018; revised: 18-7-2018; accepted: 26-3-2019)
Abstract: Parental psychological control refers to those parental behaviors that interfere with the child's thoughts and feelings and are characterized by excessive use of manipulative techniques, such as inducing guilt or shame and love-withdrawal. The goal of this study was to validate the Spanish version of the Dependency-oriented and Achievement-oriented Psychological Control Scale (DAPCS), a new measure designed to assess an adolescent's perception of psychological control. Another objective was to determine the influence of perceived parental psychological control on adolescents' self-concept. We evaluated the factor structure, reliability, and convergent validity in a sample of Spanish late adolescents $(N=310$, mean age $=19.75)$. Exploratory and confirmatory factor analyses showed that the DAPCS factor structure is best described by a two-factor solution, for both paternal and maternal ratings, indicating the distinction between dependency-oriented and achievement-oriented psychological control. High indices of internal consistency indicated that DAPCS produced reliable scores. Moreover, convergent validity was confirmed by consistent associations between the DAPCS and other measures of psychological control and other parenting dimensions. Hierarchical regression also showed that DAPCS predicted late adolescents' self-concept. The results of this study indicate that the Spanish version of the DAPCS is a useful instrument for studying both types of psychological control.

Keywords: dependency-oriented psychological control; achievementoriented psychological control; parenting; self-concept; adolescence. for fear of losing their parents' love (Barber, Olsen, \& Shagle, 1994). Behavioral control has been defined as parents' attempts to regulate and structure their children's behavior through the communication of rules and the monitoring of children's behavior (Bean, Barber, \& Crane, 2006). From this point of view, Barber and Harmon (2002, see also Barber et al. 1994; Bean et al., 2006) indicated that behavioral control protects adolescents against antisocial behavior such as drug abuse, sexual precocity, aggressiveness, and impulsivity. On the other hand, psychological control is related to personality problems such as low self-esteem or vulnerability to depression.

Soenens, Vansteenkiste and Luyten (2010) recently proposed the hypothesis that psychological control can be perceived as two dimensions: dependency-oriented psychological control and achievement-oriented psychological control. Dependency-oriented control is defined as the use of control to keep children within close physical and emotional boundaries (Soenens et al., 2010). Families that employ this kind of psychological control are characterized by a lack of inter- 
personal boundaries between members. Children are not allowed to have their own lives and experiences (Soenens et al., 2010). Achievement-oriented control is defined as the use of control to make children comply with excessive parental standards for achievement (Soenens et al., 2010). In these families, parents behave in a controlling manner toward their children demanding perfection and high levels of achievement. Clark and Coker (2009) explained that there are four types of early experience that may be associated "with perfectionistic thinking: Overly critical/demanding parenting styles; excessively high parental expectations and indirect criticism; absent, inconsistent or conditional parental approval; perfectionistic parents who model perfectionistic attitudes and behaviors" (pp. 321-322).

Both dimensions are related to different maladaptive outcomes. Dependency-oriented psychological control is related to adolescent dependency and vulnerability to depression (Gargurevich \& Soenens, 2016; Soenens et al., 2010, Soenens, Park, Vansteenkiste, \& Mouratidis, 2012). A dependent vulnerability can develop when adolescents are involved in family dynamics in which parents use manipulation to make adolescents stay in close relationships. Similarly, when parents use love, guilt or shame to pressure adolescents to be dependent, those children are likely to develop dysfunctional dependence and dysfunctional independence with regard to their parents (Kins, Soenens, \& Beyers, 2012). A dependency-oriented psychological control style also can provoke separation anxiety issues in the adolescents (Stone, Otten, Soenens, Engels, \& Janssens, 2015) and a low level of overall life satisfaction (Cacioppo, Pace \& Zappulla, 2013).

Achievement-oriented psychological control is correlated with maladaptive adjustment in adolescence. Adolescents who feel that their parents pressure them to be the best at everything are more likely to be very self-critical (Gargurevich \& Soenens, 2016; Soenens et al., 2010, 2012; Bleys et al., 2016) and they are more likely to develop maladaptive perfectionism (Clark \& Coker, 2009). In addition, parents' attempts to make their children achieve high standards encourages adolescent anxiety and depressive symptoms (Gargurevich \& Soenens, 2016; Ingoglia, Inguglia, Liga, \& Lo Coco, 2016; Inglugia et al., 2016), and a low level of overall life satisfaction (Cacioppo et al., 2013).

Few studies have analyzed the different influence of maternal or paternal dependency-oriented and achievementoriented psychological control on adolescents' adjustment. Soenens et al. (2010) found that, in middle adolescents, only maternal dependency-oriented psychological control predicted adolescent dependency, while both maternal and paternal achievement-oriented psychological control explained independent variance in adolescents' self-criticism. Kins et al. (2012) confirmed that maternal DPC and paternal APC were related to dysfunctional separation-individuation, while maternal APC and paternal DPC were unrelated to this outcome. As Kins et al. (2012) said, these results seem to suggest that DPC is more salient for mothers and APC is more salient for fathers. Finally, Bleys et al. (2016) found that both maternal and paternal achievement-oriented psychological control were related independently to adolescent selfcriticism

In order to examine and validate both dimensions, Soenens et al. (2010) constructed a new instrument called Dependency-oriented and Achievement-oriented Psychological Control (DAPCS). This instrument contains two subscales to assess both constructs, DPC and APC. That research demonstrated that the instrument is a useful, reliable scale, and allowed the two constructs to be differentiated. Soenens et al. (2010) found that both constructs were positively correlated with psychological control, which was measured through the Psychological Control Scale-Youth Self-Report (PCS-YSR). In addition, these constructs also were negatively correlated with parental autonomy support, which was measured with items from the Perception of Parents Scale (POPS) (see also Gargurevich, Soenens, \& Matos, 2016; Mantzouranis, Zimmermann, Mahaim, \& Favez, 2012). APC was also negatively associated with parental support and DPC was unrelated (in the maternal ratings) and positively related (in the paternal ratings) with parental support (for similar results see Mantzouranis et al., 2012). Moreover, divergent validity of both subscales was supported in a sample of late adolescents because both constructs were related to other parenting dimensions, DPC with enmeshment and APC with a perfectionist family climate (Soenens et al., 2010). Finally, Soenens et al. (2010) concluded that there were good positive correlations between both subscales indicating that some parents tended to use psychological control in both domains. However, it was also possible that some parents may use manipulative tactics predominantly in the dependency domain or in the achievement domain. Another study showed that "DPC and APC were positively correlated with each other, and negatively associated with PAS" (Inglugia et al., 2016, p. 426), which is a measure of parental autonomy support.

Several studies have been performed to confirm the validity and predictive capacity of the DAPCS in some countries. In a study with late adolescents by Mantzouranis et al. (2012), the French translation of the DAPCS was shown to be a valid, reliable instrument. Confirmatory factor analyses indicated that the two-factor solution of the DAPCS fit the data relatively well for both maternal and paternal ratings. The two constructs, DPC and APC, correlated strongly, the internal consistency indices of both scales were excellent and very similar to those of the original version. In addition, behavioral control, defined as parental efforts to regulate and structure the child's behavior, was positively correlated to DPC but not APC. In another sample of Italian adolescents, Cacioppo et al. (2013) confirmed the two components of psychological control, APC and DPC, and validated the psychometric properties and concurrent validity of the scale. A study by Guzzo, Lo Cascio, Pace, and Zapulla (2014) confirmed that the scale was a valid, reliable instrument in a sample of Italian-speaking adolescents, although the original 17-item structural model was not satisfactory in all the analyses. For this reason, one item was eliminated and the 16-item 
model fit the data adequately. In addition, the intercorrelation indexes of the items of both subscales were good, although the authors also indicated that they were lower than those found in previous research with late adolescents. Finally, Guzzo et al. (2014) pointed out that APC and DPC subscales correlated with strictness/supervision subscale of the Authoritative Parenting Measure.

Scharf, Rousseau \& Smith (2016) examined the validation of the DAPCS in a sample of Hebrew-speaking children, concluding that exploratory and confirmatory factor analysis supported a two-factor structure, and confirming the distinction between DPC and APC, although many items had been deleted in the development of a shorter DAPCS version for middle childhood. That research also confirmed that the mean scores were lower than those from adolescent samples. Similarly to Guzzo et al. (2014), the two dimensions correlated with each other. Negative correlations between both DPC and APC and parental emotional support indicated the convergent validity of the scale. Finally, Gargurevich et al. (2016) confirmed previous results with the DAPCS scale in terms of both validity and reliability. In that study, the two-factor structure reproduced the structure found in previous studies of DAPCS (for both paternal and maternal scores).

\section{The current study}

The aim of our research was to validate the DependencyOriented and Achievement-Oriented Psychological Control Scale (DAPCS) with Spanish late adolescents. At the moment, the DAPCS is being validated in countries with different linguistic and cultural backgrounds and our study aims to contribute its validation in the Spanish context. The main objective of the study was to assess the factorial and convergent validity and reliability of the DAPCS with a sample of Spanish late adolescents.

We expected to replicate the two-factor structure of the DAPCS and to find similar patterns of associations between DAPCS and other measures of family dimensions: psychological control, care, and overprotection. We had hypothesized that DAPCS would be positively correlated to other measures of psychological control. In addition, APC would be negatively correlated to care and overprotection, and DPC would be positively related to overprotection and unrelated or positively related to care. We also expected that both maternal and paternal dependency-oriented and achievementoriented psychological control would negatively influence late adolescents' self-concept.

\section{Method}

\section{Participants}

Students participating in this study $(N=310)$ were studying for one of three degrees (Psychology, Primary Teacher, Engineering and Computing) in Asturias (Spain),
227 were women $(73.9 \%)$ and 80 were men $(25.8 \%)$ (three students failed to indicate their sex). The mean age was 19.75 $(S D=2.73)$, but age data was lacking for 6 students. The age distribution was not normal, with absolute skewness and kurtosis values above 1 , but equality variances were assumed, $F$ $(1,302)=0.691, p>.05$. Analysis of age by gender did not yield significant differences $(t(302)=0.168, p>.05)$. The mean age for women was $19.77(S D=2.49)$, and for men, $19.71(S D=3.32)$.

\section{Procedure}

All participants voluntarily completed the questionnaires during the spring of 2017. The questionnaires were administered after obtaining permission from the appropriate university authorities. No parents withheld consent. The data were collected by members of the research team. After a short introduction, in which the researcher described the main objectives of the research, the students were asked to complete the questionnaires. Anonymity of responses was guaranteed. Participants did not receive any remuneration for their participation. The questionnaires took about $25 \mathrm{mi}$ nutes to complete.

All scales were translated from the English versions. The procedure laid out by the International Test Commission (2016) was followed for the adaptation of the instruments from source (English) to target language (Spanish). The Spanish to English back-translation could not be done by the original authors because they do not read Spanish. Three translators with an excellent command of English independently translated the items from English to Spanish. This initial version of the scales was assessed by two independent experts who evaluated the content and form of the instruments. Following that, a bilingual translator, without prior knowledge of the original versions, back-translated the Spanish versions. This translation confirmed that the Spanish versions of the different instruments were identical in content to the original versions.

\section{Measures}

Dependency-oriented and Achievement-oriented Psychological Control (DAPCS) (Soenens et al., 2010). The original scale consisted of 20 items about parental dependency-oriented psychological control (10 items), and achievement-oriented psychological control (10 items). Soenens et al., (2010) indicated that 3 items were found to have either non-significant loadings on their intended factor or to have substantial cross-loadings and should not necessarily be included in the final scale. For this reason, we performed exploratory and confirmatory factor analysis using the 17-item scale. Dependency-oriented psychological control was measured with 8 items (e.g., "My mother/father will make me feel guilty when I leave home permanently") and achievement-oriented psychological control was measured with 9 items (e.g., "My 
mother/father only shows her/his love for me when I get good grades").

Participants rated each item on 5-point likert-type scale, about their mothers and fathers separately $(1=$ Do not agree at all, to $5=$ Very strongly agree). The Cronbach's alpha values in the original version were .86 for the maternal DCP ratings and .83 for the paternal DCP ratings; and .93 for maternal APC ratings and .91 for paternal APC ratings (Soenens et al., 2010).

Other measures. In order to validate the DAPCS, we assessed two complementary measures of psychological control and one measure of other parenting dimensions, specifically care and overprotection. In addition, we measured one indicator of late adolescents' psychological adjustment: selfconcept.

Psychological Control Scale- Youth Self-Report (PCS-YSR) (Barber, 1996) and Psychological Control-Disrespect Scale (PCDS) (Barber, Xia, Olsen, McNeely, \& Bose, 2012). The first scale consists of 8 items that evaluate psychological control (e.g. "My mother/father is a person who blames me for other family members' problems"). The Cronbach's alpha value in a Spanish sample was .80 for mothers, and .83 for fathers (Authors, 2018). The second scale consists of 8 items that assess behaviors that communicate to the adolescents that they are disrespected as individuals (e.g. "My mother/father is a person who violates my privacy, e.g. entering my room, going through my things, etc.”). In the Spanish maternal group, the internal consistency was .84; and in the Spanish paternal group, the Cronbach's alpha value was .85 (Authors, 2018). In both scales, participants indicated the extent of agreement on a 3-point scale ranging from 1 (Not like her/him) to 3 (A lot like her/him). Participants rated the items for their mothers and fathers separately. Cronbach's alpha for paternal PCS was .83, while maternal PCS gave a Cronbach value of .76. The paternal PCDS Cronbach's alpha value was .85 , and the maternal PCDS Cronbach's alpha value was .83 (Rodríguez-Menéndez, Inda-Caro, Peña-Calvo, \& Viñuela-Hernández, 2018).

Parental Bonding Instrument (PBI) (Parker, Tupling \& Brown, 1979). This scale assesses two dimensions of parenting: care and overprotection. The overprotection scale consists of 13 items (e.g. "My mother/father lets me decide things for myself'), while the care scale consists of 12 items (e.g. "My mother/father speaks to me in a warm and friendly voice"). The internal consistency in the Spanish version was .86 for fathers and .82 for mothers (Rodríguez-Menéndez et al., 2018).

AF5. Autoconcepto Forma 5 (García \& Musitu, 1999). This self-report is a Spanish instrument which assess a person's self-concept in five aspects: social (e.g. "I am a friendly person"), academic/work life (e.g. "I do homework well"), emotional (e.g. "A lot of things make me nervous"), family (e.g. "My family is disappointed with me"), and physical (e.g. "I am an attractive person"). Participants responded to the 30 items with values between 1 and 99, depending on the level of agreement with the statement. The reliability of the overall scale is .82; and for each self-concept: academic, $a=.88$; social, $a=.70$; emotional, $a=.73$; family, $a=.77$ and physical, $a=.74$.

\section{Analysis plan}

Exploratory and confirmatory factor analysis aimed to examine the distinction between perceived parental DPC and APC. We expected to replicate the two-factor structure of the DAPCS. On the basis of the results of these analyses, we assessed the convergent validity of Spanish version of the DAPCS, examining the associations between the domains of psychological control and other measures of psychological control and other parenting dimensions such care and overprotection. The influence of dependency-oriented and achievement-oriented psychological control on late adolescent's self-concept was also analyzed.

\section{Exploratory and confirmatory factor analysis}

To check whether DPC and APC were in fact two specific domains of parental psychological control, two models were compared: a one-factor model in which all of the items loaded on a single psychological dimension of parental control (Model 1) and a two-factor model in which all of the items loaded on two dimensions (Model 2).

An exploratory factor analysis (EFA) and confirmatory factor analysis (CFA) were run to test the psychometric characteristics of DAPCS on two models, separately for fathers and for mothers. Firstly, the sample was divided into two different samples with the adolescents' responses for fathers $(n=294)$ and for mothers $(n=307)$. Then each sample was randomly split in half into two subsamples each for fathers $\left(n_{1}=n_{2}=147\right)$ and mothers $\left(n_{1}=154, n_{2}=153\right)$ to minimize measurement errors. This action was done automatically by the statistical program SPSS version 22.

The EFA was performed on the first subsample using the Factor program (Ferrando \& Lorenzo-Seva, 2017). The main issue was the assessment of parametric criteria in order to be able to perform this analysis: normality of sample (skewness, kurtosis) and Bartlett's and Kaiser-Meyer-Olkin's (KMO) indexes. A KMO index higher than .80 indicates that the data are suitable for factor analysis (Lloret-Segura, Ferreres-Traver, Hernández-Baeza, \& Tomás-Marco, 2014). Unweighted least squares was used as the factor extraction method. This method has been shown to be the most effective with relatively small samples (Ferrando \& AnguianoCarrasco, 2010). The oblique rotation method was used, as recommended by Lloret-Segura et al. (2014).

Following the results of the EFA, we then ran a confirmatory factor analysis (CFA) on the second subsample using MPLUS 7.3 (Muthén \& Muthén, 1998-2012) to test the structure produced by the EFA. We evaluated the fit of both EFA and CFA models using the following fit indices: ChiSquare Test of Model Fit, the comparative fit index (CFI), Tucker Lewis Index-Non-normed Fit Index (TLI-NNFI), 
the standardized root mean square residual (SRMR), and the root mean square error of approximation (RMSEA).

\section{Convergent and divergent validity}

Firstly, Pearson's correlations were calculated between DPC and APC, PCS-YSR, PCDS, and PBI to examine the relationships between the DAPCS domains and other measures of psychological control, and care and overprotection. Secondly, we performed a hierarchical regression analyses to examine the predictive power of DAPCS over student self-concept.

\section{Results}

\section{Exploratory and confirmatory factor analysis}

Factor structure. The EFA was performed using unweighted least squares as the factor extraction method. Promin was the oblique rotation method used (Lorenzo-Seva, 1999; Ferrando \& Lorenzo-Seva, 2014). The necessary criteria for the EFA were met for paternal data (Bartlett's statistic =
1400.8, $d f=120, p<.000$, and KMO test $=.88)$ and for maternal data (Bartlett's statistic $=1459.4, d f=136, p<.000$, and $\mathrm{KMO}$ test $=.88)$.

To assess the factor structure of the measure we tested two EFA measurement models (one-factor model and twofactor model). In the one-factor model (Model 1), results indicated that this model was not good fit to the paternal score data, especially the RMSR $=.10$, with the expected mean for RMSR for an acceptable model being less than .0857 (Kelley's criterion). Following that, we analyzed the communality and the standardized loading in the paternal EFA. For this reason, one DPC item (item 1) was removed from the scale. Removal of this item resulted in a seven-item paternal DPC scale and we tested the revised one-factor model eliminating item 1 from the paternal DPC score. Table 1 gives the results of the one-factor model (Model 1) exploratory factor analysis for fathers without item 1 . With the maternal data, the analyses followed the same process. Results indicated that this model was not good fit to the maternal score data. Items 1, 3 and 4 from DPC were eliminated from the final EFA solution, the final results of which are given in table 1.

Table 1. Summary of Exploratory Factor Analysis.

\begin{tabular}{lccccccc}
\hline & $\chi^{2}$ & $d f$ & $p_{\text {value }}$ & TLI-NNFI & CFI & GFI & RMSR \\
\hline Model 1 (1-factor model fathers) & 163.66 & 104 & .000 & .98 & .98 & .96 & .10 \\
Model 1 (1-factor model mothers) & 102.46 & 77 & .027 & .99 & .99 & .97 & .09 \\
Model 2 (2-factor model fathers) & 52.07 & 89 & .999 & 1.00 & 1.00 & .99 & .05 \\
Model 2 (2-factor model mothers) & 64.47 & 103 & .998 & 1.00 & 1.00 & .99 & .05 \\
\hline
\end{tabular}

Note. TLI-NNFI = Tucker Lewis Index - Non-normed Fit Index; CFI = comparative fit index; GFI = goodness of fit index; RMSR= Root Mean Square of
Residuals

We performed a new EFA with a two-factor model measurement (Model 2) for paternal and for maternal scores. For the maternal data, the results in table 1 indicated good model fit indices. For the paternal data, this model was not bad, but we decided to remove item 1 because it exhibited a very low communality and load. For this reason, we tested the revised two-factor model eliminating item 1 from the pa- ternal DPC score with better fit indices. Table 1 gives the results of the two-factor model (Model 2) exploratory factor analysis for paternal data without item 1 . Table 2 shows the EFA loads into each factor. The fit indices support the twofactor solution better for both paternal and maternal scores (Model 2).

Table 2. Exploratory Factor loadings for Dependency-Oriented and Achievement-Oriented Psychological Control Scale (DAPCS) (Model $2=$ two factors). Fathers' version $\left(\mathrm{n}_{1}=147\right) /$ Mothers' version $\left(\mathrm{n}_{1}=154\right)$ [Spanish version].

Items Factor loadings

F1 (DPC) F2 (APC)

My mother/My father.../ Mi madre /Mi padre

1. shows that $\mathrm{s} /$ he is disappointed with me if I do not rely on her/him for a problem [se siente decepcionado si no le confío mis problemas]

2. blames me that I no longer want to do things that we used to enjoy [me culpa de que ya no quiera volver a hacer cosas que solíamos disfrutar juntos]

3. will make me feel guilty when I will leave home permanently [me hará sentir culpable cuando me vaya de casa para vivir independientemente]

4. shows that $\mathrm{s} /$ he is disappointed in me if I do not want to share certain things with him/her [se siente decepcionado conmigo si no comparto ciertos intereses, ideas, pensamientos e inquietudes con el/ella] 5. is only happy with me if I rely exclusively on her/him for advice [solo es feliz conmigo si le pido consejo exclusivamente]

6. only shows her/his love for me as long as we keep doing everything together [solo me manifiesta cariño siempre y cuando sigamos haciendo todo juntos]

$.68 / .57$

$.74 / .34$ $/ .31$ 


\begin{tabular}{lc}
\hline & Factor loadings \\
\cline { 2 - 2 } Items & F1 (DPC) \\
\cline { 2 - 2 } Father/Mother Father/Mother \\
\hline 7. interferes in my problems, even if I prefer to solve them myself [interfiere en mis problemas, incluso \\
cuando prefiero resolverlos por mí mismo/a] \\
8. is only friendly with me if I rely on her/ him instead of on my friends [solo se lleva bien conmigo si \\
confío en el/ella en vez de en mis amigos] \\
9. is less friendly with me if I perform less than perfectly [es menos amable conmigo cuando no rindo \\
perfectamente en las actividades que realizo] \\
10. is less attentive to me if I do not perform up to my fullest potential [está menos atento conmigo si no \\
rindo a mi máximo potencial en las actividades que realizo] \\
11. shows that s/he loves me less if I perform badly [muestra que me quiere menos si tengo malos resul- \\
tados en las actividades que realizo] \\
12. makes me feel guilty if my performance is inferior [me hace sentir culpable si mi rendimiento es malo \\
en las actividades que realizo] \\
13. only shows her/his love for me if I get good grades [solo muestra que me quiere si saco buenas notas] \\
14. only respects me if I am the best at everything [solo me respeta si soy el mejor en todo] \\
15. is only friendly with me if I excel in everything I do [solo se lleva bien conmigo si destaco en todo lo \\
que hago] \\
16. appreciates me more if I pursue high standards [me quiere más si persigo buenos resultados en las ac- \\
tividades que realizo] \\
17. is only proud of me if I perform well on exams [solo está orgulloso de mí si tengo éxito en los exáme- \\
nes] \\
\hline Note: loadings lower than .30 omitted
\end{tabular}

The CFA with the second subsample allowed the factor structure model based on the final EFAs to be confirmed, which were: Model 1 for fathers without item 1, Model 1 for mothers without items 1, 3 and 4; and Model 2 for fathers without item 1 and Model 2 for mothers with all items for the scale. The CFA was carried out with 142 mothers (eleven cases with missing values) and 143 fathers (four cases with missing values). Table 3 shows that model 2 demonstrated better fit than model 1 , which provided preliminary evidence about the distinction between DPC and APC, both for mothers and for fathers, in the Spanish context. Nevertheless, despite the improved fit of model 2 for the maternal subsample, the results were still unsatisfactory. Because of that, item 1 had to be removed for not having appropriate statistical parameters and we tested a revised two-factor model, the results of which indicated a good fit for the maternal model (Table 3).

Table 3. Summary of Confirmatory Factor Analysis.

\begin{tabular}{|c|c|c|c|c|c|c|c|}
\hline & $\chi^{2}$ & $d f$ & $p_{\text {value }}$ & TLI-NNFI & CFI & RMSA & SRMR \\
\hline Model 1 (1-factor model fathers) & 187.91 & 101 & .000 & .82 & .85 & .08 & .09 \\
\hline Model 1 (1-factor model mothers) & 203.18 & 100 & .000 & .82 & .85 & .09 & .09 \\
\hline Model 2 (2-factor model fathers) & 133.77 & 98 & .010 & .92 & .94 & .05 & .07 \\
\hline Model 2 (2-factor model mothers) & 130.92 & 94 & .007 & .93 & .95 & .05 & .07 \\
\hline
\end{tabular}

Note. TLI-NNFI =Tucker Lewis Index - Non-normed Fit Index; CFI = Comparative Fit Index; RMSA = Root Mean Square Error of Approximation; $\mathrm{SRMR}=$ Standardized Root Mean Square Residual

Table 4 gives the final confirmatory factor loadings in each domain. Factor analysis produced solutions with good fit indices for mothers with 16 items (7 DPC items and 9 APC items). The Cronbach's alpha coefficient for the whole scale was .89. The 2 factor model produced a good fit with paternal data, giving 16 items (7 DPC items and 9 APC items). The Cronbach's alpha coefficient for the whole scale was .93.

Table 4. Confirmatory Factor loadings for Dependency-Oriented and Achievement-Oriented Psychological Control Scale (DAPCS), reliability. Fathers' items $\left(n_{2}=143\right) /$ Mothers' items $\left(n_{2}=142\right)$ [Spanish version]

\begin{tabular}{|c|c|c|c|c|}
\hline Items & Loads & Mean & Variance & Reliability \\
\hline & Father/Mother & Father/Mother & Father/Mother & Father/Mother \\
\hline $\begin{array}{l}\text { Dependency-Oriented Psychological Control (DPC) } \\
\text { My mother/My father.../ Mi madre / Mi padre }\end{array}$ & & & & $.90 / .83$ \\
\hline $\begin{array}{l}\text { 1. shows that } \mathrm{s} / \text { he is disappointed with me if I do not rely on her/him } \\
\text { for a problem [se siente decepcionado si no le confío mis problemas] }\end{array}$ & $-1-$ & $-/-$ & $-1-$ & \\
\hline $\begin{array}{l}\text { 2. blames me that I no longer want to do things that we used to enjoy } \\
\text { [me culpa de que ya no quiera volver a hacer cosas que solíamos disfru- } \\
\text { tar juntos] }\end{array}$ & $.36 / .64$ & $1.63 / 1.90$ & $0.85 / 1.36$ & \\
\hline
\end{tabular}




\begin{tabular}{|c|c|c|c|c|}
\hline Items & Loads & Mean & Variance & Reliability \\
\hline & Father/Mother & Father/Mother & Father/Mother & Father/Mother \\
\hline $\begin{array}{l}\text { 3. will make me feel guilty when I will leave home permanently [me ha- } \\
\text { rá sentir culpable cuando me vaya de casa para vivir independientemen- } \\
\text { te] }\end{array}$ & $.37 / .58$ & $1.17 / 1.44$ & $0.33 / 0.82$ & \\
\hline $\begin{array}{l}\text { 4. shows that } \mathrm{s} / \mathrm{he} \text { is disappointed in me if I do not want to share cer- } \\
\text { tain things with him/her [se siente decepcionado conmigo si no com- } \\
\text { parto ciertos intereses, ideas, pensamientos e inquietudes con el/ella] }\end{array}$ & $.40 / .44$ & $2.11 / 2.24$ & $1.17 / 1.59$ & \\
\hline $\begin{array}{l}\text { 5. is only happy with me if I rely exclusively on her/him for advice [so- } \\
\text { lo es feliz conmigo si le pido consejo exclusivamente] }\end{array}$ & $.64 / .59$ & $1.18 / 1.36$ & $0.25 / 0.61$ & \\
\hline $\begin{array}{l}\text { 6. only shows her/his love for me as long as we keep doing everything } \\
\text { together [solo me manifiesta cariño siempre y cuando sigamos haciendo } \\
\text { todo juntos] }\end{array}$ & $.71 / .41$ & $1.18 / 1.21$ & $0.28 / 0.28$ & \\
\hline $\begin{array}{l}\text { 7. interferes in my problems, even if I prefer to solve them myself [in- } \\
\text { terfiere en mis problemas, incluso cuando prefiero resolverlos por mí } \\
\text { mismo/a] }\end{array}$ & $.36 / 55$ & $1.60 / 2.02$ & $0.80 / 1.23$ & \\
\hline $\begin{array}{l}\text { 8. is only friendly with me if I rely on her/ him instead of on my } \\
\text { friends [solo se lleva bien conmigo si confío en el/ella en vez de en mis } \\
\text { amigos] }\end{array}$ & $.77 / .58$ & $1.18 / 1.34$ & $0.39 / 0.54$ & \\
\hline Achievement-Oriented Psychological Control Scale (APC) & & & & $.94 / .95$ \\
\hline $\begin{array}{l}\text { 9. is less friendly with me if I perform less than perfectly [es meno } \\
\text { amable conmigo cuando no rindo perfectamente en las actividades que } \\
\text { realizo] }\end{array}$ & $.54 / .36$ & $1.88 / 2.06$ & $1.42 / 1.56$ & \\
\hline $\begin{array}{l}\text { 10. is less attentive to me if I do not perform up to my fullest potential } \\
\text { [está menos atento conmigo si no rindo a mi máximo potencial en las } \\
\text { actividades que realizo] }\end{array}$ & $.37 / .76$ & $1.57 / 1.68$ & $0.80 / 1.17$ & \\
\hline $\begin{array}{l}\text { 11. shows that } \mathrm{s} / \text { he loves me less if I perform badly [muestra que me } \\
\text { quiere menos si tengo malos resultados en las actividades que realizo] }\end{array}$ & $.85 / .88$ & $1.28 / 1.47$ & $0.61 / 0.98$ & \\
\hline $\begin{array}{l}\text { 12. makes me feel guilty if my performance is inferior [me hace sentir } \\
\text { culpable si mi rendimiento es malo en las actividades que realizo] }\end{array}$ & $.48 / .69$ & $1.83 / 2.13$ & $1.30 / 1.69$ & \\
\hline $\begin{array}{l}\text { 13. only shows her/his love for me if I get good grades [solo muestra } \\
\text { que me quiere si saco buenas notas] }\end{array}$ & $.88 / .81$ & $1.23 / 1.32$ & $0.44 / 0.53$ & \\
\hline $\begin{array}{l}\text { 14. only respects me if I am the best at everything [solo me respeta si } \\
\text { soy el mejor en todo] }\end{array}$ & $.67 / .67$ & $1.25 / 1.15$ & $0.58 / 0.24$ & \\
\hline $\begin{array}{l}\text { 15. is only friendly with me if I excel in everything I do [solo se lleva } \\
\text { bien conmigo si destaco en todo lo que hago] }\end{array}$ & $.67 / .73$ & $1.20 / 1.25$ & $0.44 / 0.43$ & \\
\hline $\begin{array}{l}\text { 16. appreciates me more if I pursue high standards [me quiere más si } \\
\text { persigo buenos resultados en las actividades que realizo] }\end{array}$ & $.67 / .68$ & $1.53 / 1.63$ & $0.90 / 1.01$ & \\
\hline $\begin{array}{l}\text { 17. is only proud of me if I perform well on exams [solo está orgulloso } \\
\text { de mí si tengo éxito en los exámenes] }\end{array}$ & $.83 / .73$ & $1.40 / 1.57$ & $0.71 / 0.91$ & \\
\hline
\end{tabular}

The confirmatory factor analyses using the Spanish questionnaire indicate that the two-factor solution of the DAPCS proposed by Soenens et al. (2010) fits our data relatively well in both maternal and paternal versions.

\section{Convergent and divergent validity}

Given that the factor structure was similar for perceptions about fathers and mothers, we ran Pearson's correlation between the PCS-YSR, PCDS, PBI and DAPCS scales (Table 5). The correlations between these variables and AF-5 self-concept was included.

Table 5. Summary of Intercorrelations from DAPCS, PCS, PCDS, PBI and AF5.

\begin{tabular}{|c|c|c|c|c|c|c|c|c|c|c|c|c|c|c|c|c|}
\hline Variable & 1 & 2 & 3 & 4 & 5 & 6 & 7 & 8 & 9 & 10 & 11 & 12 & 13 & 14 & 15 & 16 \\
\hline 1. DPC mother & & & & & & & & & & & & & & & & \\
\hline 2. DPC father & $.746^{* * *}$ & & & & & & & & & & & & & & & \\
\hline 3. APC mother & $.469^{* * *}$ & $.360^{* * *}$ & & & & & & & & & & & & & & \\
\hline 4. APC father & $.488^{* * *}$ & $.580^{* * *}$ & $.708^{* * *}$ & & & & & & & & & & & & & \\
\hline 5. PCS mother & $.478^{* * *}$ & $.290^{* * *}$ & $.598^{* * *}$ & $.431^{* * *}$ & & & & & & & & & & & & \\
\hline 6. PCS father & $.461^{* * *}$ & $.601^{* * *}$ & $.396^{* * *}$ & $.652^{* * *}$ & $.508^{* * *}$ & & & & & & & & & & & \\
\hline 7. PCDS mother & $.499^{* * *}$ & $.309^{* * *}$ & $.739^{* * *}$ & $.510^{* * *}$ & $.757^{* * *}$ & $.416^{* * *}$ & & & & & & & & & & \\
\hline 8. PCDS father & $.445^{* * *}$ & $.525^{* * *}$ & $.409^{* * *}$ & $.685^{* * *}$ & $.410^{* * *}$ & $.715^{* * *}$ & $.476^{* * *}$ & & & & & & & & & \\
\hline 9. PBI Care mother & $-.274^{* * *}$ & $-.190^{* * *}$ & $-.610^{* * *}$ & $-.420^{* * *}$ & $-.562^{* * *}$ & $-.320^{* * *}$ & $-.623^{* * *}$ & ${ }^{*}-.341^{* * *}$ & & & & & & & & \\
\hline 10. PBI Care father & $-.330^{* * *}$ & $-.313^{* * *}$ & $-.362^{* * *}$ & $-.563^{* * *}$ & $-.342^{* * *}$ & $-.514^{* * *}$ & $-.353^{* * *}$ & $*-.563^{* * *}$ & $* .564^{* * *}$ & & & & & & & \\
\hline 11. PBI Overprotection mother & $.551^{* * *}$ & $.334^{* * *}$ & $.412^{* * *}$ & $.334^{* * *}$ & $.514^{* * *}$ & $.299^{* * *}$ & $.523^{* * *}$ & $.224^{* * *}$ & $-.340^{* * *}$ & $-.236^{* * *}$ & & & & & & \\
\hline
\end{tabular}




\begin{tabular}{|c|c|c|c|c|c|c|c|c|c|c|c|c|c|c|c|c|}
\hline Variable & 1 & 2 & 3 & 4 & 5 & 6 & 7 & 8 & 9 & 10 & 11 & 12 & 13 & 14 & 15 & 16 \\
\hline 12. PBI Overprotection father & $.326^{* * *}$ & $.403^{* * *}$ & $223^{* * *}$ & $.365^{* * *}$ & $.285^{* * *}$ & $.388^{* * *}$ & $.312^{* * *}$ & $.400^{* * *}$ & $-.208^{* * *}$ & $-.239^{* * *}$ & $.573^{* * *}$ & & & & & \\
\hline 13. Academic self-concept & -.075 & -.054 & $-.181^{* *}$ & $-.156^{* *}$ & $-.147^{*}$ & $-.122^{*}$ & $-.194^{* * *}$ & $-.158^{* *}$ & $.217^{* * *}$ & $.215^{* * *}$ & -.005 & -.005 & & & & \\
\hline 14. Social self-concept & -.098 & -.063 & -.051 & -.105 & $-.172^{* *}$ & -.055 & -.105 & $-.203^{* * *}$ & $.189^{* * *}$ & $.269^{* * *}$ & -.043 & -.102 & $.311^{* * *}$ & & & \\
\hline 15. Emotional self-concept & -.051 & -.110 & -.077 & -.053 & -.098 & .000 & -.084 & -.084 & .039 & -.047 & -.087 & $-.282^{* * *}$ & -.026. & $.321^{* * *}$ & & \\
\hline 16. Family self-concept & $-.410^{* * *}$ & $-.348^{* * *}$ & $-.636^{* * *}$ & $-.582^{* * *}$ & $-.568^{* * *}$ & $-.428^{* * *}$ & $-.655^{* * *}$ & $-.491^{* * *}$ & $.720^{* * *}$ & $.513^{* * *}$ & $-.350^{* * *}$ & $-.226^{* * *}$ & $.315^{* * *}$. & $.275^{* * *}$ & .079 & \\
\hline 17. Physical self-concept & -.052 & -.027 & -.073 & -.092 & -.103 & -.104 & -.102 & $-.145^{*}$ & $.181^{* *}$ & $.187^{* *}$ & -.023 & -.038 & $.385^{* * *}$. & $.424^{* * *}$. & $142^{*}$ & $204^{* * *}$ \\
\hline
\end{tabular}

Correlations between the perception of the maternal and paternal care dimension and the DPC and APC scales were negative (Table5), while the correlations of these scales with the perception of parental control (PCS and PCDS) and overprotection were positive.

Because DPC and APC were significantly correlated (Table5), it was necessary to control for their shared variance in order to determine their unique associations with the comparison measures. Partial correlations were consequently computed, allowing examination of the associations of each domain of psychological control with the validation measures (Table 6).

Table 6. Correlations and partial correlations between DAPCS' subscales and dimensions of psychological control, care and overprotection.

\begin{tabular}{|c|c|c|c|c|}
\hline & \multicolumn{2}{|l|}{$\mathrm{DPC}$} & \multicolumn{2}{|l|}{$\mathrm{APC}$} \\
\hline & $\mathrm{r}$ & Partial 1 & $\mathrm{r}$ & Partial $r$ \\
\hline \multicolumn{5}{|l|}{ Maternal ratings } \\
\hline PCS mother & $.478^{* * *}$ & $.325^{* * *}$ & $.603^{* * *}$ & $.506^{* * *}$ \\
\hline PCDS mother & $.499^{* * *}$ & $.287^{* * *}$ & $.739^{* * *}$ & $.690^{* * *}$ \\
\hline PBI Care mother & $-.274^{* * *}$ & .060 & $-.610^{* * *}$ & $-.610^{* * *}$ \\
\hline PBI Overprotection mother & $.551^{* * *}$ & $.430^{* * * *}$ & $.412^{* * *}$ & $.253^{* * *}$ \\
\hline \multicolumn{5}{|l|}{ Paternal ratings } \\
\hline PCS father & $.601^{* * *}$ & $.357^{* * *}$ & $.652^{* * *}$ & $.463^{* * *}$ \\
\hline PCDS father & $.525^{* * *}$ & $.172^{* * *}$ & $.685^{* * *}$ & $.581^{* * *}$ \\
\hline PBI Care father & $-.313^{* * *}$ & -.013 & $-.563^{* * *}$ & $-.491^{* * *}$ \\
\hline PBI Overprotection father & $.403^{* * *}$ & $.247^{* * *}$ & $.365^{* * *}$ &, $176^{* * *}$ \\
\hline
\end{tabular}

Overall, both DAPCS subscales were positively associated with a general measure of psychological control and the measure of overprotection. When controlling for the variance shared between DPC and APC, both still exhibited significant positive correlations with measures of psychological control (maternal and paternal PCS and PCDS), and paternal and maternal overprotection. Both DPC and APC showed negative correlations with maternal and paternal ratings about care, but when we controlled for their shared variance, only APC was significantly and negatively correlated with care, whereas DPC was not.

Predictive validity. To analyze the predictive power of both parental domains, a hierarchical regression was performed with the five kinds of self-concept assessed through AF5 as criterion variables (data not shown). The increase in predictive validity of adding one predictor variable in each step was analyzed. In step 1, maternal dependency-oriented psychological control was added, in step 2 paternal dependencyoriented psychological control was added, maternal achievement-oriented psychological control in step 3 and, finally in step 4, paternal achievement-oriented psychological control. The data show that DAPCS exhibited good predictive validity and Variance Inflation Factor (VIF) values were lower than 5 . The percentage of explained variance in family selfconcept was $46 \%\left(R^{2}=.46\right)$, both maternal DPC and APC negatively influence the development of family-self-control, and only paternal APC led to poor family self-concept.

Maternal achievement-oriented psychological control negatively influences the adolescents' academic self-concept, while paternal achievement-oriented psychological control negatively affects their social self-concept. Also, paternal dependency-oriented psychological control is detrimental to the adolescents' emotional self-concept.

Nevertheless, paternal and maternal scores were strongly correlated with each other and this may mean that when a maternal measure predicts an outcome, the corresponding paternal measure may not predict it. This might not be because that paternal measure is not predictive, but rather because its effect is obscured by the effect of the maternal measure. For this reason, we ran a model with maternal measures only, and a model with paternal measures only (Table 7).

Table 7. Predictive Validity of the Dependency-Oriented and Achievement-Oriented Psychological Control Scale (DAPCS): Hierarchical Regression Analyses Predicting Late Adolescent's Self-concept.

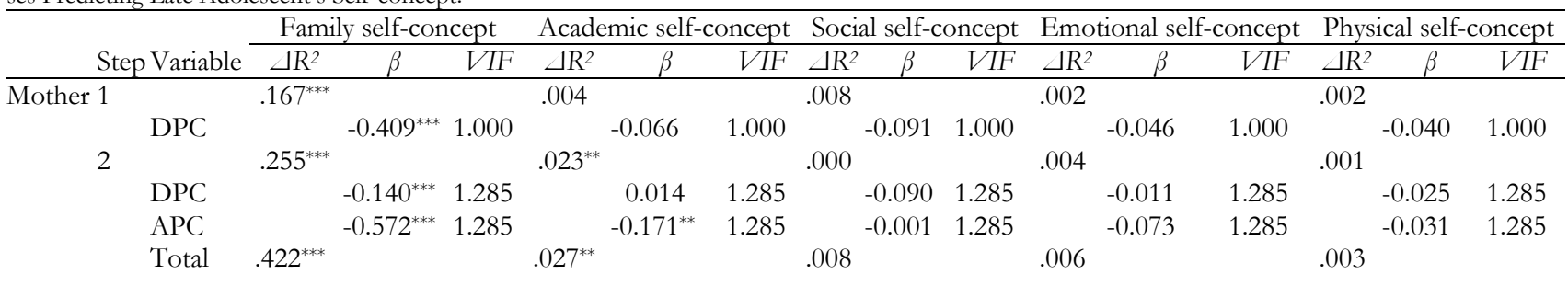




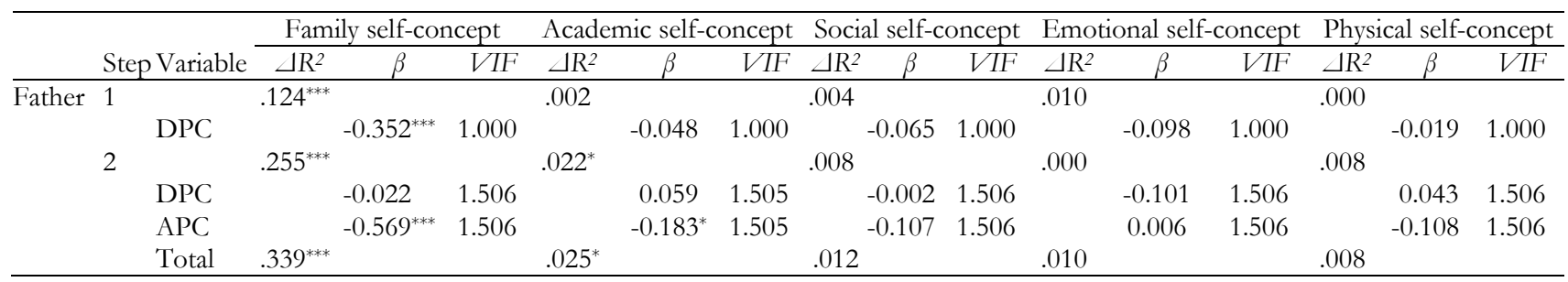

$* p<.05 .{ }^{* *} p<.01 .{ }^{* * *} p<.001$.

Both maternal DPC and APC negatively influenced the development of family-self-control and, in this case, both paternal DPC and APC predict poor family self-concept. The percentage of variance explained was greater for mothers $\left(R^{2}\right.$ $=.422)$ than fathers $\left(R^{2}=.339\right)$, as was the greater negative influence on academic self-concept.

\section{Discussion}

Our aim with this research was to validate the Spanish-form of the Dependency-oriented and Achievement-oriented Psychological control Scale (DAPCS) in a sample of late adolescents. Our results showed that the instrument is a useful and reliable scale. Exploratory and confirmatory factor analysis support a two factor structure, in line with other studies (Cacioppo et al., 2013; Guzzo et al., 2014; Mantzouranis et al., 2012; Scharf et al., 2016; Soenens et al., 2010), confirming the distinction between DPC and APC with paternal and maternal ratings. It seems that parental psychological control is a multidimensional construct and that this manipulative parenting tactic can assume different forms which can have differing effects on children's and adolescents' adjustment.

However, we must also note that the original 17-item structural model was not satisfactory in all the analyses. For this reason, one item was eliminated and the 16-item model adequately fit the data. One item was also eliminated from the APC scale in the study by Guzzo et al. (2014) whereas in our study the item was eliminated from the DPC scale ("My mother/father shows that $\mathrm{s} /$ he is disappointed with me if I do not rely on her/him for a problem"). Similarly, in Scharf et al. (2016) the DAPCS was adapted to middle childhood and many items were deleted resulting in a shorter version.

In addition, the two subscales correlated positively with each other, in line with other studies (Guzzo et al., 2014; Inglugia et al., 2016; Mantzouranis et al., 2012; Scharf et al., 2016; Soenens et al., 2010). For this reason we can conclude that parents who use tactics to keep their children physically and emotionally close are more likely to use psychological control to press their children to excel in achievement related situations. However, it is also possible that some parents may have a parenting style which is characterized by the use of dependency-oriented psychological control, whereas other parents may be more prone to using achievement-oriented psychological control. Similarly, there were high correlations between maternal and paternal APC and maternal and pater- nal DPC. The size of these correlations indicates that late adolescents perceived that when one parent used a specific type of psychological control, the other parent used it too.

Our results are similar to other studies which have found correlations between DAPCS and other measures of psychological control and different parenting dimensions. For maternal and paternal ratings, DPC and APC were positively correlated to PCS-YSR and PCDS, which are both general measures of perceived parental psychological control developed by Barber (1996) and Barber et al. (2012). PCS-YSR measures parental psychological control understood as a manipulative parental behavior which dominates the adolescents in the interests of parental demands or expectations. PCDS measures coercive parental behaviors which disrespect the adolescent, such as, ridiculing, embarrassing in public, invalidating, violation of privacy, induction of guilt, excessive expectations, comparing to others, and ignoring. It seems that general measures of perceived parental psychological control are in concordance with DAPCS, an instrument which measures two dimensions of this general construct, which is consistent with the literature (Gargurevich et al, 2016; Mantzouranis et al., 2012; Soenens et al., 2010).

DPC and APC correlated positively with a measure of parental overprotection. Other studies (Guzzo et al., 2014) have found DPC to be significantly positively correlated with parental overprotection but APC to not be related to overprotection. In our study, when adolescents perceived that their parents, both mothers and fathers, used manipulative behaviors to keep them emotionally dependent and to make them comply with parents' high expectations of achievement, they also perceived that their parents played an overprotective role that limited their ability to think and act on their own.

Our results also demonstrated that DPC and APC were negatively correlated with parental care, but when we controlled for their shared variance, only APC was significantly and negatively correlated with care. In other words, when the adolescents perceived that their parents used psychological control to demand high levels of perfection and achievement from them, they also felt that their parents did not exercise a caregiving role. Similar results have been found in other studies which indicate the negative correlations between DAPCS and other positive family dimensions related to care, such us parental autonomy support (Gargurevich, et al., 2016; Inglugia et al., 2016; Mantzouranis et al., 2012; Soenens et al., 2010), responsiveness/support (Mantzouranis et al., 2012), or emotional support (Scharf et al., 2016). For this 
reason, we can conclude that psychological control and care are incompatible parenting dimensions.

Finally, another of our aims was to analyze the influence of both types of psychological control on late adolescents' self-concept because the image that a person has of themselves is a fundamental construct in the development of psychosocial well-being. Moreover, self-concept is constructed in the context of the social interactions that the person establishes, especially with significant others such as parents. Our results indicate that both types of parental psychological control are negatively correlated with some dimensions of late adolescents' self- concept, specially family self-concept. Hence, our study contributes to the literature about the negative influence of dependency-oriented psychological control and achievement-oriented psychological control on adolescent adjustment (Bleys et al.; Cacioppo et al., 2013; Clark \& Coker, 2009; Gargurevich \& Soenens, 2016; Ingoglia et al., 2016; Inglugia et al., 2016; Kins et al., 2012; Soenens et al., 2010, 2012; Stone et al., 2015).

The results of our study show that each type of psychological control influences different self-concept dimensions. When parents have high expectations of achievement that are communicated through coercion and the use of psychological control to keep adolescents within close physical and emotional boundaries, the adolescents have a more negative family self-concept. Our data also show that the influence of achievement-oriented psychological control is stronger than the influence of dependency oriented psychological control. Moreover, our results indicate that maternal psychological control exhibits more influence than paternal psychological control. Family self-concept refers to the feeling of being involved in the family and to being accepted by other family members. For this reason, it is logical that when parents manipulate their children through tactics such as love withdrawal, or inducing guilt or shame, late adolescents' have a poorer perception of their participation, integration and involvement in the family environment.

Similarly, parental achievement-oriented psychological control was also negatively correlated with academic selfconcept, especially for maternal data. When mothers and fathers exercised psychological control, making adolescents comply with excessive standards for performance, the adolescents had a more negative perception about their performance as students. This result has important educational implications because it shows that parental pressure to achieve has negative consequences on academic self-concept. Psychological pressure that is exerted to achieve high standards can have the opposite effect and negatively influence adolescents' academic self-concept, which can in turn influence negative school engagement (Aguirre, Revuelta \& Zulaika, 2016).

\section{Limitations and future research}

Various limitations should be considered, all of which prompt suggestions for future research. Firstly, our research examined the psychometric properties of the DAPCS with a homogeneous sample. Women were overrepresented in the sample $(73.9 \%$ of the sample were female). In addition, the local population in this part of Spain is not ethnically diverse. For this reason, we did not ask the participants in our study about their ethnicity. The study should be replicated with more diverse samples to achieve more generally applicable results. Additionally, in our study adolescents were not asked about their socioeconomic status, parents' educational level or family structure. These variables should be taken into account in future studies to provide more generalizable results.

Secondly, the methodological approach has some limitations. The variables were assessed through self-report questionnaires, the data only reflected the adolescents' perceptions of controlling parental behaviors. This perception is a good approximation because the subjective experiences of psychologically controlling parenting is vitally important in research on internalizing problems (Brenning, Soenens, Van Petegem, \& Vansteenkiste. 2015), but it is also necessary to complement this information with the parent's perception of their own behavior. Future research should be carried out with a multi-informant design approach to advance the development of knowledge in parenting research. Another possible way to obtain a more holistic interpretation is to complement the data obtained through self-report questionnaires with data from an observational approach. The inclusion of ratings of observed parent-adolescent dyads has several advantages because the effects of social desirability can be controlled (Wuyts, Soenens, Vansteenkiste, Van Petegem, \& Brenning, 2017) and observation would permit better interpretation of the way in which parental psychological control manifests.

Our research demonstrates that both subscales correlate positively but it seems that some parents can be characterized by using a specific type of psychological control. Soenens et al. (2010) indicated that future research, using a person-oriented approach, should be performed to identify different parental profiles. It is necessary to investigate how parental and adolescent variables can influence the development of a style of psychological control more oriented to dependence or more oriented to achievement.

In summary, this study tested one instrument developed to measure both types of psychological control in a late adolescent Spanish sample. The findings support the reliability and validity of the DAPCS and demonstrate the influence of both types of psychosocial control on late adolescents' selfconcept.

Acknowledgments. - We gratefully acknowledge the permission of Professor Bart Soenens (University of Gent) to adapt the instrument for the Spanish population. 


\section{References}

Aguirre, A., Revuelta, L., \& Zulaika, L.M. (2016). La influencia de los dominios específicos del autoconcepto en la implicación escolar del alumnado de educación secundaria [The influence of the specific domains of self-concept on the school involvement of secondary school students]. In J.L. Castejón Costa (Coord.), Psicología y Educación: Presente y Futuro (pp. 264-271). Alicante: ACIPE.

Barber, B. (1996). Parental psychological control: revisiting a neglected construct. Child Development, 67, 3296-3319.

Barber, B., \& Harmon, E.L. (2002). Violating the self: parental psychological control of children and adolescents. In B.K. Barber (Ed.), Intrusive parenting: How psychological control affects children and adolescents (pp. 15-52). Washington, DC: American Psychological Association.

Barber, B., Olsen, J.E., \& Shagle, S.C. (1994). Associations between parental psychological and behavioral control and youth internalized and externalized behaviors. Child Development, 65, 1120-1136. Doi: $10.2307 / 1131309$

Barber, B., Xia, M., Olsen, J., McNeely, C., \& Bose, K. (2012). Feeling disrespected by parents: refining the measurement and understanding of psychological control. Journal of Adolescence, 35, 273-287. Doi: 10.1016/j.adolescence.2011.10.010

Bean, R., Barber, B., \& Crane, D. (2006). Parental support, behavioral control, and psychological control among African American youth. Journal of Family Issues, 27, 1335-1355. Doi: 10.1177/0192513X06289649

Bleys, D., Soenens, B., Boone, L., Claes, S., Vliegen, N., \& Luyten, P. (2016). The role of intergenerational similarity and parenting in adolescent self-criticism: an actor-partner interdependence model. Journal of Adolescence, 49, 68-76. Doi: 10.1016/j.adolescence.2016.03.003

Brenning, K., Soenens, B., Van Petegem, S., \& Vansteenkiste, M. (2015). Perceived maternal autonomy support and early adolescent emotion regulation: a longitudinal study. Social Development, 24, 561-578. Doi: 10.1111 /sode. 12107

Cacioppo, M., Pace, U., \& Zappulla, C. (2013). Parental psychological control, quality of family context and life satisfaction among Italian adolescents. Child Indicators Research, 6, 179-191. Doi: 10.1007/s12187-0129164-4

Clark, S., \& Coker, S. (2009). Perfectionism, self-criticism and maternal criticism: a study of mothers and their children. Personality and Individual Differences, 47, 321-325. Doi: 10.1016/i.paid.2009.03.020

Ferrando, P. J., \& Anguiano-Carrasco, C. (2010). El análisis factorial como técnica de investigación en psicología. [Factor analysis as a research technique in psychology]. Papeles del Psicólogo, 31, 18-33.

Ferrando, P. J., \& Lorenzo-Seva, U. (2014). El análisis factorial exploratorio de los ítems: algunas consideraciones adicionales [Exploratory Item Factor Analysis: Some additional considerations]. Anales de Psicología, 30(3), 1170-1175. Doi: 10.6018/analesps.30.3.199991

Ferrando, P. J., \& Lorenzo-Seva, U. (2017). Program Factor at 10: Origins, development and future directions. Psicothema, 29(2), 236-240.

García, F. \& Musitu, G. (1999). AF5. Autoconcepto Forma 5. Manual. [AF5. Self-concept. Manual. 5 Version] Madrid: TEA Ediciones.

Gargurevich, R., \& Soenens, B. (2016). Psychologically controlling parenting and personality vulnerability to depression: a study in Peruvian late adolescents. Journal of Child and Family Studies, 25(3), 911-921. Doi: 10.1007/s10826-015-0265-9

Gargurevich, R., Soenens, B., \& Matos, L. (2016). Propiedades psicométricas de la escala de control psicológico orientado a la dependencia y a la autocrítica (DAPCS-S) en adolescentes tardíos de Lima [Psychometric properties of the dependency-oriented and achievement-oriented psychological control scale (DAPCS-S) in late adolescents from Lima]. Interamerican Journal of Psychology, 50(2), 248-264.

Guzzo, G., Lo Cascio, V., Pace, U. \& Zapulla, C. (2014). Psychometric properties and convergent validity of the dependency-oriented psycho- logical control and achievement-oriented psychological control Scale (DAPCS) with Italian adolescents. Journal of Child and Family Studies, 23 1258-1267. Doi: 10.1007/s10826-013-9786-2

Ingoglia, S., Inguglia, C., Liga, F., \& Lo Coco, A. (2016). Associations between perceived parental psychological control and internalizing difficulties in emerging adulthood: the role of identity. Journal of Social and Personal Relationships, 1-14. Doi: 10.1177/0265407516670760

Inglugia, C., Inglogia, S., Liga, F., Lo Coco, A., Lo Cricchio, M.G., Musso, P., ... Lim, H.J. (2016). Parenting dimensions and internalizing difficulties in Italian and U.S. emerging adults: the intervening role of autonomy and relatedness. Journal of Child and Family Studies, 25, 419-431. Doi: $10.1007 /$ s10826-015-0228-1

International Test Commission. (2016). The ITC Guidelines for Translating and Adapting Tests (Second edition). [www.InTestCom.org]

Kins, E., Soenens, B., \& Beyers, W. (2012). Parental psychological control and dysfunctional separation-individuation: a tale of two different dynamics. Journal of Adolescence, 35, 1099-1109. Doi: 10.1016/j.adolescence.2012.02.017.

Lorenzo-Seva, U. (1999). Promin: A method for oblique factor rotation. Multivariate Behavioral Research, 34, 347-365. Doi: 10.1207/S15327906MBR3403_3

Lloret-Segura, S., Ferreres-Traver, A., Hernández-Baeza, A., \& TomásMarco, I. (2014). El análisis factorial exploratorio de los ítems: una guía práctica, revisada y actualizada [Exploratory Item Factor Analysis: A practical guide revised and updated]. Anales de Psicología, 30(3), 11511169. Doi: 10.6018/analesps.30.3.199361

Mantzouranis, G., Zimmermann, G., Mahaim, E.B., \& Favez, N. (2012). A further examination of the distinction between dependency-oriented parental psychological control and achievement-oriented parental psychological control: Psychometric properties of the DAPCS with French-speaking late adolescents. Journal of Child and Family Studies, 21, 726-733. Doi: 10.1007/s10826-011-9525-5

Muthén, L. K., \& Muthén, B. O. (1998-2012). Mplus user's guide (7th Ed.). Los Angeles: Muthén \& Muthén.

Parker, G., Tupling, H., \& Brown, L.B. (1979). A parental bonding instrument. British Journal of Medical Psychology, 52, 1-10.

Rodríguez-Menéndez, C., Inda-Caro, M., Peña-Calvo, J.V., \& ViñuelaHernández, P. (2018). Perceived parental autonomy support and parental control in Spanish Late-Adolescents. Manuscript submitted for publication.

Scharf, M., Rousseau, S., \& Smith, Y. (2016). Validation of the dependencyoriented psychological control and achievement-oriented psychological control Scale in middle childhood. Journal of Child and Family Studies, 25, 1200-1207. Doi: 10.1007/s10826-015-0286-4

Soenens, B., Vansteenkiste, M., \& Luyten, P. (2010). Toward a domainspecific approach to the study of parental psychological control: distinguishing between dependency-oriented psychological control and achievement-oriented psychological control. Journal of Personality, 78(1), 217-256. Doi: 10.1111/j.1467-6494.2009.00614.x

Soenens, B., Park, S-Y., Vansteenkiste, M., \& Mouratidis, A. (2012). Perceived parental psychological control and adolescents' depressive experiences: a cross-cultural study with Belgian and South-Korean adolescents. Journal of Adolescence, 35, 261-272. Doi: 10.1016/j.adolescence.2011.05.001

Stone, L., Otten, R., Soenens, B., Engels, R., \& Janssens J. (2015). Relations between parental and child separation anxiety: the role of dependencyoriented psychological control. Journal of Child and Family Studies, 24, 3192-3199. Doi: 10.1007/s10826-015-0122-x

Wuyts, D., Soenens, B., Vansteenkiste, M., Van Petegem, S., \& Brenning, K. (2017). The role of separation anxiety in mother's use of autonomy support: an observational study. Journal of Child and Family Studies, 26, 1949-1957. 